\title{
The United States Recognition for the United Arab Republic: Why?
}

\author{
Rania Ali Maher
}

\begin{abstract}
Throughout the 1950's, relations between the United States and Egypt vacillated widely from relative amicability to salient confrontations. Whereas containment of the communist menace and forming intra-regional coalitions were the focal points of the US foreign policy in the Middle East, eliminating Western influence and establishing Egypt as the dominant actor in the Arab world directed Nasser's policy. This conflict of interests came to a head in the aftermath of the Suez Crisis and the declaration of Eisenhower Doctrine. However, by the beginning of 1958, the State Department realized that its efforts to halt Nasser's growing power in the Arab world had failed and that the only way they could achieve their objectives in the region was by reestablishing a working relationship with Nasser and his newly-formed United Arab Republic. Taking this as an initial point, the main purpose of this paper is to answer the question: Why did the United States recognize the UAR despite the threats it represented to its interests?
\end{abstract}

Keywords Eisenhower Doctrine, Nasser, Communism, Syrian Crisis of 1957, United Arab Republic.

\section{Egyptian-American Relations: From Hostility to Amity}

By the declaration of Eisenhower Doctrine in January 1957, relations between Egypt and the United States reached low ebb. While the Doctrine was presented as a means to counter Soviet penetration in the Middle East, this new policy appeared to be based primarily on circumscribing Nasser's power and influence in the Arab world, which were enormously strengthened following the Suez Crisis. To achieve this, the American policymakers sought to isolate Nasser from his allies, Saudi Arabia, Jordan and Syria, and then build a strong anti-communist alliance without Egypt (FRUS XII 195557: no.161).

Since March 1956, the Eisenhower administration had decided, "to build up an Arab rival of Nasser", who could challenge his leadership in the region and could halt the increasing communist influence in which he appeared to be supporting (FRUS XVI 1955-57: no.650). Meanwhile, Nasser's rising popularity and the accompanying expansion of the revolutionary Arab 
nationalism tenets caused the conservative Arab royal countries to reassess their positions towards Egypt (Dawisha 2003).

Because of Saudi Arabia's possession of the world's largest reserves of oil and its important position in the Islamic world, Eisenhower and Dulles chose King Saud as a counterpoise to Nasser, believing "that mutually antagonistic personal ambitions might disrupt the aggressive plans" of Nasser (Ferrell 1981: 323).

The official visit of Saud to Washington in January 1957 marked the real beginning of the US effort to bolster Saud's standing in the Arab World and his conversion to the pro-West camp. This was clearly manifested in Saudi Arabia conciliatory approach towards Iraq -a member in Baghdad Pact- after a long and bitter enmity with the Hashemite dynasty. In their meeting in Washington, King Saud and Iraqi Crown Prince Abd al-Ilah pledged to patch up their differences and to exchange visits and ambassadors for the first time (Lesch 1992; Yaqub, 1999).

During the Arab Conference that held in Cairo on February 26-27, Saud also exerted great efforts to bring the US point of view closer to that of the Arab leaders to the extent that Nasser complained that he acted as if he were the US President's representative. In the meetings, Saud showed openly that he was against positive neutralism and in sympathy with a pro-Western policy (NA RG 59 684A.86/2-2857; Al-'Azm 1973).

The Jordanian crisis of 1957, then, portrayed the break-up of Nasser-Saud alliance completely when the latter decided to dispatch a Saudi contingent to Jordan to support King Hussein against his pro-Nasser prime minister, Sulayman al-Nabulsi. The situation in Jordan had reached crisis point when Nabulsi gained more popularity at the King's expense because of his new policy that epitomized in obstinately condemnation of the Eisenhower Doctrine, accepting foreign aid from the Soviet Union, backing stronger ties with Cairo and Moscow, the abrogation of the Anglo-Jordanian treaty of alliance and its replacement by the Arab Solidarity Pact between Jordan, Saudi Arabia, Syria and Egypt (Yaqub 1999). Therefore, Hussein forced the resignation of his prime minister on April 10, claiming that his country was threatened by communism, in an attempt to secure American support. The State Department responded cursorily, mobilizing units of the Sixth fleet to a forward position in the Eastern Mediterranean and providing the King with $\$ 10$ million of emergency aid. On the other hand, it convinced Saudi Arabia and Iraq to support Hussein with military aid (FRUS XXIII 1955-57: no. 76; 83). Receiving such backing, Hussein publicly blamed Nasser and accused Egypt of being behind the turmoil in Jordan. He then declared martial law, 
and arrested Nabulsi and many of his followers (Dawisha 2003). In response, Nasser, through Cairo radio, unleashed a propaganda campaign against Hussein and the United States, describing the crisis as an American plot and the King as an agent of imperialism (Holland 1994; Geary 2007).

After the crisis, King Saud made his first official visit to Iraq where he declared that the Baghdad Pact was "of advantage to the Arab world" and showed his strong opposition to Nasser by sending an unofficial message to both the British and the Americans via Nuri Said, the Iraqi Prime Minister, advising them of withholding any financial or economic aid to the Egyptian president, with the aim of maintaining the maximum pressure on the already straitened Egyptian economy. He believed that this would be the better way to force Nasser to turn to him for help, so he would seize the opportunity to compel Nasser to mitigate his pro-Soviet policy (McNamara 2005; Podeh 1993).

Thus, it can be said that by the mid-1957, the United States had achieved its aim of dismantling the Arab Solidarity Pact and forming a new royalist coalition between Saudi Arabia, Jordan and Iraq, leaving Nasser with only Syria as an ally.

Nasser, by his turn, had understood perfectly that the United States thumped in accomplishing its policy of isolating Egypt and containing his influence in the Arab world. He also realized the importance of not losing Syria either to the Western or Eastern camp, as this would inevitably end his dream of Egypt's prerogative for Arab hegemony (Podeh 1993; McNamara 2005).

With the approach of autumn, Nasser met this challenge when Syria became a zone of regional and international struggle. The crisis officially started on August 13 when the Syrian government announced the expulsion of three American diplomats for their involvement in a conspiracy to overthrow the regime in Damascus, which the State Department believed was about to becoming a Soviet satellite in the region. In response, the US declared, on the next day, the Syrian ambassador in Washington and his second secretary persona non grata (FRUS XIII 1955-57: no. 355).

Previously and throughout 1956 and 1957, the Eisenhower administration had worried about what it saw as a growing Soviet infiltration in Syria. This feeling was intensified by a number of events occurred in the second half of 1957. The bid for building a new Syrian oil refinery at Homs was awarded to a Czech company after a fierce contest with an American corporation (FRUS XIII 1955-57: no. 349). This was followed by the signing of a wide-ranging technical and economic agreement with the Soviet Union. Then came finally the appointment of a suspected communist, Afif al-Bizri, as Syria's new commander-in-chief (FRUS XIII 1955-57: no. 359). In addition to the predominance of the Ba'athists and Communists in the Syrian government since their big triumph at the polls in May (Lesch 1992), the State Department perceived those actions to be paving the way for unacceptable 
communist seizure of the country. Similarly, Nasser was progressively disturbed by the growing communist influence in the Syrian government at the expense of the nationalists (Ba'athists and pro-Nasserists), a matter that would ultimately let Syria to slip away from his domain and would challenge his doctrine of positive neutralism (Yaqub 1999; Al Otaiby 2002).

Hence, both Eisenhower and Dulles looked for intervening actions that would prevent the loss of the Middle East to communism (FRUS XIII 1955-57: no.182). They decided to send Loy Henderson, Deputy Under Secretary of State for Administration, to urge Syria's conservative Arab neighbors to form a regional alliance including Turkey against Damascus. Realizing that a unilateral action would inflame the Arab world against the United States, Henderson, in his meeting with Turkish, Iraqi, Jordanian and Lebanese high officials, made it clear that the United States would only back Iraqi-Jordanian and Turkish military intervention into Syria that had the nature, which could be justified in the United Nations (FRUS XIII 1955-57: no. 364; 374). The American plan was to create justification for invoking the Eisenhower Doctrine by inciting Turkey and Iraq to mass their troops along their borders with Syria in an attempt to provoke a clash with the Syrian army. On the same time, the US committed itself to provide them with arms and to preclude any Israeli or Russian intrusion (Lesch 1995; Geary 2007; Eisenhower 1965).

Henderson's mission merely aroused a great storm of anti-Western propaganda (Lesch 1992; Sorby 2000). As a result of the relentless campaign unleashed by Cairo radio for weeks against American imperialism and its agents in the region, and due to their apprehension of Arab masses backlash, Syria's pro-Western Arab neighbors disavowed the idea of launching a military attack against it (Geary 2007; Al-Jebarn 1988; Dawish 2003). On the contrary, they showed great support to the Syrian government. King Saud, the most likely candidate for leading the Arab action against Damascus, was the first to blow a rash retreat, blaming Washington for creating superfluous problem in the Middle East (FRUS XIII 1955-57: no. 375; Eisenhower 1965). He regarded the US-Syrian crisis as an opportune moment to assert the leadership role assigned to him by Washington, but in his own way. He played the role of arbitrator, travelling between Arab capitals to ease tensions (Lesch 1992; Anderson 1995). Consequently, the Lebanese, Jordanian and Iraqi governments baked down from attacking the Syrian regime, declaring their solidarity with it and denouncing any aggression against the government in Damascus (Eisenhower 1965; Lesch 1995; Ashton 1996). 
With the failure of the Administration to gain an all-Arab response in the way it had envisioned, the United States was left with Turkey as the only country that continued to show anti-Syrian sentiment and apply military pressure on the Syrian's frontier. However, this path raised the tension to the international level, as the Soviet Union intervened and issued harsh direct threats against Turkey, a NATO member (McNamara 2005; Little 1990; Eisenhower 1965). The Soviets regarded the crisis as a chance to enhance their position in the Middle East by representing themselves as allies and supporters of their potential patron state (Sorby 2000).

On the other hand, by the early of October, Saud had been portrayed as "the lion of peninsula", because of his efforts in unifying the Arabs together against the imperialist forces, countering Nasser's regional leadership (McNamara 2005: 104).

Faced with this unacceptable course of events -the attempts of the Soviet Union to replace Egypt as Syria's military defender and that of Saud to assume the role of the Arab's leader at the expense of him- Nasser decided to take an active role in the crisis. By one spectacular move, he succeeded in restoring his prestige, sending a contingent of Egyptian troops to the Syrian port of Latakia on October 13. It was a merely figurative deployment, as the number of Egyptian troops landed was not sufficient for the purported mission, but in its symbolism, it had a great impact on Arab masses opinion. It portrayed Nasser as the incontrovertible leader of Arab nationalist movement and the savior of Syria against imperialism (Lesch 1998; McNamara 2005; Dawisha 2003). Accordingly, by this masterstroke, Nasser upstaged Saud, sustained Syria's bent toward Egypt, strengthened the position of the Ba'ath Party and the pro-Egyptian officers in the Syrian army and thus halted the growing Soviet influence in Syria at Egypt's expense (Lesch 1995). He was skillful enough in restoring his prestige in the region, not only at the expense of his Arab rivals, but also at the expense of his former allies, the Soviets and their communist partners inside the Syrian government (McNamara 2005).

In addition, Cairo's intervening maneuver posed a serious question in the State Department concerning the US stance towards Nasser who had emerged as the only one capable of combating communism in Syria. On November 4, William Rountree -the Assistant Secretary- reported that Nasser was concerned about Egypt's growing economic dependence on the Soviet Union as well as the threats which the Soviet-Syrian rapprochement might represent to his influence in the Arab world (FRUS XVII 1955-57: no. 392). He confirmed that Nasser was interested in improving Cairo relations with Washington. As a sign to illustrate Egypt's good intention, the Egyptian foreign minister played a vital role in convincing the Syrians not to proceed with their complaint against Turkey in front of the United Nations in the time that the Soviets were pushing them to do so (FRUS XIII 1955-57: no. 412; 
417). Nasser's attitude led Eisenhower, himself, to think critically about the reassessment of the US position towards Egypt, asking Dulles on November 13 about the possibility of initiating a drive to bring Nasser back to their side. He recommended that this should be done skillfully in a way that they would not be in the position of "bootlicking a dictator" (FRUS XVII 1955-57: no. 398).

Thus, the Syrian crisis ended in a victory for Nasser and the Syrians and a clear failure for the Eisenhower Doctrine policies. It proved that the Eisenhower administration had completely misread the scene in the Middle East. They realized that the little could be done without Nasser (Kerr 1967). Hence, it can be said that if the year of 1957 witnessed the high tide of the American-led front against Nasser, it created, by its end, a congenial atmosphere for Egypt and the United States to reach a "modus vivendi" (Lesch 1992).

\section{A Change in Plans: United States' Rapprochement with Egypt and Syria:}

Realizing that the growing Soviet influence in the region threatened his own policy of Egyptian leadership of the Arab world and his independent position vis-à-vis the superpowers, and that the United States had the power to stymie his role in the region, Nasser became convinced that he should move to the West.

On the other hand, the State Department realized that playing off Arab rivalries had become ineffective or even counterproductive. It merely increased instability, hostility towards Washington and opened the door to Soviet penetration. Thus, the Administration figured out that it would have to reconsider its relation with Nasser, as he became, willy-nilly, "the symbol of radical Arab nationalism." (FRUS VXII 1955-57: no. 367).

Therefore, the Egyptian-American rapprochement, after the Syrian crisis, did not occur abruptly. There had been some signs earlier that their mutual interests, particularly regarding Syria, produced some sort of temporary accommodation (Lesch 1995).

As early as the summer of 1957, Nasser made it clear to the United States, through Raymond Hare, its ambassador in Cairo, that he was seeking better relations with Washington. He stressed that although Egypt had a satisfactory relationship with the Soviet Union, but this did not mean that he was supporting communism. He affirmed that it was the US policy which was forced him to shift towards the Russians (FRUS XVII 1955-57: no.334; 350). In a statement to the Associated Press and the National American 
Broadcasting Company on September 27, 1957, Nasser expressed his willing to improve Egypt's relations with the United States and that he had no objection to have a meeting with President Eisenhower on the condition that the latter would take the initiation (Nasser's Speeches 1957). On the ground, Nasser ordered the Egyptian press and radio to moderate their propaganda attacks on the United States. He, then, declared that Egypt would resume its trade relations with the West, preliminary with France (Lesch 1995). In spite of concluding new agreements with the Soviets for Egypt economic development, the Egyptian government announced the arrest of 18 Egyptian communists for conspiring a coup against Nasser to verify that the latter was independent and was opposing communism (Heikal 1988). On the other hand, he offered the Syrian government the use of Egyptian technicians instead of Soviets in the training of the Syrian army in order to ease the tension in the American-Syrian relations and to reduce Syria's reliance on Soviet aid (FRUS XIII 1955-57: no. 379).

In December, Nasser accentuated his desire for closer relations by sending several emissaries to the Eisenhower administration showing Egypt concern for keeping Syria from falling too deeply into the Soviet orbit. On December 9, Dulles met Mahmoud Fawzi, the Egyptian Foreign Minister, who conveyed Nasser's point of view concerning the Syrian matter, saying that Egypt believed that the communist threat in Syria was exaggerated, and that "in the coming months we might hear of reassuring developments [there]" that would prove Nasser's sincerity towards US. On the next day, Ali Sabry, Nasser's political advisor, revealed to Hare that the main difference between the United States and Egypt was their attitude toward nationalism, confirming that nationalism had no link with communism, and Egypt was more concerned about the impact of communism in the region than the United States "since Egypt had to live in the area and could not escape the consequences" (NA RG 59 674.00/12-1157).

On December 11, Nasser sent Mohammed Heikal, his friend and confidant, to the US Embassy in Cairo to deliver a "very urgent and serious message." He informed Hare that the President had checked the CIA reports sent to him about the Syrian officials who had become Soviet proxies and he believed that something should be done about them. He assumed that this was Egypt's responsibility; and that any American or Turkish intervention in the Syrian problem would have drastic results and Egypt was the only country that could successfully intervene "with minimal repercussions." He then asked the United States for giving Egypt a free hand in Syria for only three months to impede the communist influence there. Without revealing the details of Nasser's plan, Heikal concluded the message with the assurance that this information should be used with "absolute secrecy" (FRUS XIII 1955-57: no. 420). 
Having exhausted all obtainable opportunities, Dulles had no choice except to do business with Nasser. He promptly accepted Nasser's proposal, but he stressed that his approval did not mean that the US would bind itself from taking actions to protect its interests in Syria. On the other hand, Hare had been informed that the State Department would arrange with Egypt for the appointment a new ambassador in Damascus, believing that this would give them the chance for exerting their influence there (FRUS XIII 1955-57: no. 421). However, Dulles stressed that they should proceed most cautiously, as Nasser might try to play the US and USSR off against each other in order to enhance his position in the area (FRUS XVII 1955-57: no. 413).

On the other hand, Nasser's mediation paved the way for an American-Syrian rapprochement, convincing both parties that direct negotiations would be the only path to ease tension (NA RG 59 783.00/8-3157). Meetings between the American officials and $\mathrm{Ba}$ 'ath leaders reflected the desire of the American and Syrians to enhance their relations. In his meeting with the Assistant Secretary of State on November 7, Salah el-Bitar, the Syrian Foreign Minister, made no secret of the Syrian government desire "to normalize the diplomatic situation with the US and ..... to find ways and means of improving relations." (FRUS XIII 1955-57: no. 419). On January 10, 1958, Ba'ath Party sent three representatives to Alfred Atherton, the US consul in Aleppo, asking for US backing and for using its power to preclude any turmoil on the Syrian borders from the Israeli or Turkish sides. They assured that the Ba'ath Party was dominating the main vital positions in the army and that they would intervene in the next parliamentary elections to curb communist influence, urging the US to support Bitar to achieve this aim. At the same time, they asked for keeping their contacts with Akram Al-Hourani, a prominent member of Ba'ath Party and the speaker of the Syrian parliament, at the minimum so as to not to give the chance to the communists of accusing him of being working under US direction (NA RG 59 611.83/12558).

Accordingly, the incidents of the year prompted all parties to re-evaluate their attitudes towards each other. Nasser understood that any drastic action in Syria to eliminate communist influence would not succeed on its own but required the American support or at least its blessing (Podeh 1999). From the Syrian side, Ba'ath Party and other nationalist elements realized the dangers represented by the Communist Party's members, who became more active in Syrian political arena and gained more prestige at their own expense (Seale 1965). 
Besides, the Eisenhower administration acknowledged the failure of its policies in the Middle East. The weight of evidence showed that the methods it used to eliminate the Soviet influence there produced the opposite effect. It inflamed the nationalist sensibilities of the entire region against US. Many top American policy advisers and even Eisenhower himself came to the conclusion that they should follow a new policy accommodated with Arab nationalism and its leader, Nasser (Geary 2007).

On January 10, the NSC Planning Board, headed by Robert Cutler, the President special assistant for national security affairs, submitted a longdetailed report under the title; "Long-Rang U.S. Policy toward the Near East", in which they stressed that "current trends in the Near East [were] unfavorable to Western interests; US and Western influence [had] declined, while Soviet influence [had] greatly increased". They added that "many Arabs identified the US with the colonial and ex-colonial powers in the area". The paper stated that there was a substantial belief within the area that the US was seeking to protect its interest in the region by opposing any political or economic progress, while the Soviet Union supported the goals of Arab nationalism. Also, the majority of the Arabs believed that the US sought "to keep the Arab world disunited in order to dominate the area and [was] committed to work with reactionary elements..." Accordingly, the NSC recommended the termination of the policy of isolating Nasser, the acceptance of his policy of neutralism that became "a permanent factor in the Near East political arena", and the cooperation with Egypt where matters of common interest were involved, specifying the limitation of "communist control in Syria." They also emphasized the importance of the proclamation of U.S. support for "the ideal of Arab unity" between two or more Arab states who had good relations with Washington, nominating Saudi Arabia, Jordan and Iraq (FRUS XII 1958-60: no. 3).

Consequently, the assumption that the US instigated the program of normalizing its relations with Nasser after the Lebanese crisis and the Iraqi revolution of 1958 had been refuted by the declassification of the mentioned report. However, it should be borne in mind that this program did not come into force until the formation of UAR because of Dulles' reluctance to accept Nasser's positive neutralism.

\section{The US Position toward the Formation of the UAR:}

While Washington was holding the meetings for the discussion of the NSC report and debating the best approach for dealing with Nasser, Egypt and Syria were in the process of the formation of the UAR. It is beyond the scope of this paper to discuss the details behind the merging of Egypt and Syria in the United Arab Republic, but one scene of that story should be mentioned. According to the Egyptian and Syrian accounts, Egypt was not the one who initiated the drive for unity with Syria. It was not part of Nasser's plan to 
assume complete authority over the Syrian government in the immediate future, all he had sought was to monitor its foreign policy, as he did not want to be involved in the internal affairs of the country. Nasser discerned the political, economic and institutional differences between the two countries, and the Egyptians and international reservations that would make the immediate unity with Syria a risky scheme. However, under pressure from the Syrians, Nasser acceded to the union even though he knew that such move would represent a financial burden for Egypt and would create additional problems for him in the international arena (Eisenhower 1965; Jankowski 2002). Realizing the dramatic consequences of rejecting the Syrian's plea on his image as the preeminent Arab leader (Nutting 1972), Nasser justified his acquiescence to the Syrian, saying: "[I] had taken [the] plunge because there was no alternative and without much thought about outside reaction..." (FRUS XIII 1958-1960: no. 197). But as a price for his approval, he insisted on having an integral union between the two countries rather than a federal one, as some Syrians had preferred, and considered the exclusion of the Syrian army from politics and the dissolution of all the Syrian's political parties as indispensable preconditions for proclaiming the union. He also demanded the holding of a plebiscite in Egypt and Syria to demonstrate public support for the unification. Syria's internal political instability, the external threats and the great popular enthusiasm to Nasser gave the Syrian leaders no option except to submit to the Egyptian terms, deeming that "no one would dare to say no to unity...the public would tear their heads off." (Jankowski 2002: 106). As a result, on February 1, 1958, President Nasser and President Quwatli announced, from Abdeen Palace in Cairo, the creation of the United Arab Republic and the selection of Nasser as its first president (Barrett 2007).

Since Nasser was keen for keeping the United States abreast of his steps in Syria, seeking its backing, so he sent Heikal to the US Embassy on the same day he reached a settlement with Bitar, informing them that the Syrian Foreign Minister had been successful in urging Nasser to accept the union. Heikal was also so smart in reassuring the US Embassy official that the suggested move would be within the context of the secret green light given to Nasser by Dulles on December 12, 1957 for acting in Syria, divulging that Nasser had decided to dismiss both Al-'Azm and Bizri, the two suspected communists, from their positions once he took control of the situation there (NA RG 59 674.83/1-2158).

Nevertheless, the declassified documents do not evidently indicate whether a similar Egyptian diplomatic approach was made to the Soviets or not (Podeh 
1999), however, it has been confirmed that Nasser was expecting Soviet opposition to the union (FRUS XIII 1958-60: no. 197; Taha 1974). Accordingly, it can be said that while the State Department was not surprised by the union, confusion and perplexity dominated the scene in the Kremlin, particularly because of Nasser's plan to eradicate the Communist Party in Syria (Holland 1994).

Unaware of the secret early contacts between Egypt and the United States, President Quwatli, Prime Minister 'Asali and Minister Bitar approached the State Department to ensure its blessing. In their meetings with the new American Ambassador, Charles Yost in January 1958, they revealed their desire for dissipating misunderstandings and enhancing the relations between the two countries. They also raised the question of Arab unity and expressed their hopes that the United States would not oppose the union as it had countered the Tripartite agreement of 1955 before (FRUS XIII 1958-60: no.185).

The news of the creation of the UAR reached Washington while Dulles was attending the annual meeting of Baghdad Pact Council at Ankara in late January. His absence from office caused him to draw conclusions based more on his instincts rather than on clear evidences and at odds with his own State Department (Ashton 1996).

Believing that the USSR was behind the move toward union, Dulles called for a specially restricted session of the Council on January 28, in which he expressed his opinion about the dangerous of the union on the Western interests in the region, claiming that it might drag both Jordon and Lebanon under its domination, leaving Iraq and Saudi Arabia in risk. In other words, he elucidated that such arrangement would not only placed the Arab states under Nasser's control, but actually it would put them under the Soviets' domination. He urged a rapid action from the Arab states against the union that would be certainly supported by the United States, stressing that Washington would not take the lead as it did during the Syrian crisis (FRUS XII 1958-60: no. 9).

In a private meeting with the Iraqi delegation, headed by Nuri al-Sa'id, whom Dulles regarded as "the key to the situation", the latter went so far in his pledges, emboldening Nuri's plot of fomenting a tribal revolt in northern Syria against the union and permitting Iraq to annex sections of northeastern Syria with US backing (FRUS XIII 1958-60: no. 193).

However, Dulles's harsh reaction had been tempered on the next day when he received intelligence reports, advocating the anticommunist origins of the Egyptian-Syrian union (Eveland 1980). Regretting his impetuosity in encouraging an early Iraqi's initiative, Dulles took a more prudent line in the next session, suggesting a multilateral Arab-led response to the union, as "if Iraq [would] alone oppose", he said "it would be accused of acting on influence of non-Arab BP powers and while that would be better than doing 
nothing it would not be as helpful as a common position." He recommended that Baghdad Pact should not make a statement condemning union in the present time, as they should wait for the other Arab countries' reactions. $\mathrm{He}$ promised that the US would urge Saudi Arabi, Jordan and Lebanon to arrange for a common Arab action with Iraq against the union which they "considered dangerous" (FRUS XIII 1958-60: no. 188).

Returning back to Washington, Dulles found himself isolated from the State Department, which formed a cautious assessment of the implications of the Egyptian-Syrian merger. All the reports from American diplomats in the region and US intelligence pointed out that the union was a Syrian initiative by the Ba'athists and their allies in the army to eliminate the growth of communist influence in the Syrian's government and army, and that Nasser had been forced to accede to the Syrian's appeal in order to maintain his prestige in the Arab world as the leader of Arab nationalism. The Near Eastern Affairs office report on January 21 recommended the acceptance of the union as the United States was not in a position "to prevent some kind of union from taking place...". Although the union had long-term disadvantages on the US's interests, as it would facilitate Egypt's domination of Arab world at the expense of Saudi Arabia and Iraq, and it might exacerbate Egypt-Syria relations with Israel, however, they stressed that its short-term advantage outweighed what could be seen as disadvantages, believing that "if EgyptianSyrian union were accompanied by effective measures to eliminate entirely the influence of the Syrian Communist Party and its allies," this would be adequate for the present time (FRUS XIII 1958-60: no. 186; 187).

In the $354^{\text {th }}$ meeting of the National Security Council that held on February 6, Dulles, in a manner that had "the flavor of an apology" (Ashton 1996), provided the Council with an explanation for his reckless promise of encouraging Iraqi expansionism of Syria and for his harsh attitude in Ankara, stating: "There had been practically no solid intelligence at Ankara as to how this union had actually come about. Intelligence material available in the Near East does not compare in quantity or quality with what is available to us here in Washington, and the U.S. Delegation accordingly felt very isolated and very much in the dark." In addition, he justified that "There was strong pressure on the United States to speak out against the union." In the same meeting, Allen Dulles, CIA Director, underlined that the USSR was not behind the union and there was an opposition to the union by the Syrian communists and even Moscow itself had been "puzzled as to what attitude to take", thus, the United States, the CIA recommended, should seized the opportunity to weak these two countries (FRUS XII 1958-60: no. 10). 
Hence, Dulles had no option except to retreat from his confrontational approach to Nasser and the new unity. He, then, instructed NEA to examine the possibility of "extending the hand of friendship" to the UAR, as "it might be a good and profitable occasion" particularly that "the Soviets [were] hesitant about their attitude to the union."

Nevertheless, Dulles still had hopes for a common Arab action against the union (FRUS XIII 1958-60: no. 191). Despite the fact that the establishment of the UAR set off a wave of confusion and panic among the conservative regimes in the Arab world, no one could condemn it publicly. As mentioned before, Iraq was the first country that showed hostility to the union during Ankara meeting and Crown Prince 'Abd al-Ilah induced the members of Baghdad Pact not to recognize the UAR on the ground that it had been initiated by Nasser to control the Arab world and it was pushed by the Soviets, thus, it constituted a great dangerous not only to Iraq, but to all the members and it should be opposed (FRUS XII 1958-60: no. 9). King Hussein of Jordan also declared to the American Ambassador in Amman that the UAR posed dire threat not only to Jordan and Lebanon, but to the free world and that he called for the revival of treaties for economic and military integration between Iraq, Jordan and Saudi (FRUS XI 1958-60: no. 157). For Saudi Arabia, although King Saud was angry and acknowledged the dangerous of such move on his position, but he was "unenthusiastic" about taking part in a common action against the union (Eisenhower 1965). On February 7, Saud informed the US that it would be "better not to take any opposing measures re Egypt-Syrian union so long as...[it did] not harm any other Arab state.....'(FRUS XIII 1958-60: no. 193). Thus, lack of Saud's support meant the failure of Dulles's plan for formulating a common Arab action to combat the union.

On the next day, Dulles was obliged to withdraw his recent pledge at Ankara BP meeting of supporting an Iraqi operation in Syria. He sent a decent rejection to the Crown Prince, mentioning the obstacles that would hinder the implementation of the Iraqi's plan, especially that Washington had "no reports of any widespread opposition in Syria to the union" and that the Syrian tribes had been "subjected [to] strict surveillance and control by [the] Syrian military." Accordingly, "US and Iraq.... would find themselves in an extremely difficult position if they should move...to break up [the] union without.... official support of non-union Arab states, especially Saudi Arabia." (FRUS XIII 1958-60: no. 193). The US's apathetic reaction to the union was so disappointed to the conservative Arab leaders, particularly to Iraq (Podeh 1999).

Realizing that the recognition of the UAR was inevitable, Dulles advised Eisenhower on February 8 "to extend recognition to the new republic as soon as such step is appropriate........", as the United States would not be able to stand alone against the union "without giving offense to the popular appeal of 
Arab nationalism", especially that the Arab states could not adopt any common action and one or more of them were about to recognize the UAR (FRUS XIII 1958-60: no. 194).

He also informed the British that although they had the tools to stir up troubles for Nasser in front of the formation of the UAR, but they were now believed that this would only cause Nasser to move closer to USSR and would pave the way for developing the new republic as "a wholly communist controlled state" (McNamara 2005: 118).

Nasser, by his turn, again approached the State Department, four days before holding the plebiscite, but this time by himself when he summoned Hare on February 17 to belay any possible opposition. He was afraid that his intention might be misinterpreted, so he firstly clarified that at the time he made his secret approach to Hare through Heikal in last December, "he had no thought of Egyptian-Syrian union except as something which might be worked out in five years or so." He then used the communist menace as a device to induce Washington not to oppose the union, saying: “.... There was no real government in Syria. Kuwatly resigned five times. Azm had made alliance with Communists and was planning organized new party which would probably have been sort of Communist front. Collapse was imminent. Syrian conservatives and businessmen also came to say union necessary to save from Communists. Only the name of Nasser could save the situation (this stated factually rather than arrogantly)." Nasser stressed that he would be able to handle the situation, "but it [would] be rough going" (FRUS XIII 1958-60: no. 197). In other words, he presented the union to Washington as an act to forestall a communist coup in Syria.

By February 15, it became obvious for the Eisenhower administration that the United Arab Republic was a fact and they would have to take advantage of it. In its circular telegram to Amman, Baghdad, Beirut, Jidda, Khartoum, Ankara, Karachi, London, Tehran, Cairo, Damascus, Paris and Tel Aviv, the State Department made it clear that the recognition of the UAR would be dovetailed with American interests, as this step would give the US the chance "to assert a certain amount of constructive influence upon [Nasser]", whose popularity was now at the peak in the Arab world. The telegram, also, avowed that it would not be in the interests of the US and its Arab friends to withhold recognition in the time that the concept of unity had a great popular appeal among the Arab masses (FRUS XIII 1958-60: no. 196). In another confirmation of the same assessment, Dulles wrote to the Iraqi's government on February 21 declaring that: "withholding recognition would be politically 
disadvantageous and that we should establish correct relations with UAR from outset." (FRUS XIII 1958-60: no. 199).

By going through the State Department documents, it can be easily concluded that the quick recognition of the UAR was supported by the CIA, US ambassadors in Egypt and Syria, and by most of the officials in the State Department believing that the new republic might provide the US with opportunities to bring Nasser back to their side and it might create some sort of competition between Nasser and the Soviets. Therefore, it was of little surprise that the United States extended recognition to the UAR on February 25 , just three days after the proclamation of the results of the plebiscite.

\section{Conclusion}

It can be stated clearly that by the end of 1957, the State Department had reached the conclusion that Nasser could be neither unheeded nor toppled in the near future. The Eisenhower Doctrine, which was designed to isolate him and undermine his domestic and regional power produced nothing except a vehement opposition to the US among the Arab masses. Nasser's triumph in the battle over Syria had dealt a severe blow not only to the Eisenhower administration and his regional enemies, but also to the Soviets. He became a "regional hero" with no competitor in sight. Though, it took Eisenhower and Dulles some time to recognize that Washington could not feasibly win over the Arab world without reaching an accommodation with Nasser, the creation of UAR added a sense of urgency to change the direction of US policy in the Middle East. There was a growing belief in the administration that the Egyptian-Syrian merger would provide Washington with opportunities to bring Nasser back into a more neutral stance and keep Syria from becoming a Soviet base in the region, especially after seeing all of their previous efforts in the region come to an unsuccessful end, and ironically, were only successful in bringing Syria closer to the Soviets.

In spite of their concern about the long-term implications of the union, the State Department realized that the only attainable solution to the Syrian problem was to be under Nasser's command, who courted the Americans with displays of moderation and sobriety during the last few months of 1957. On the other hand, the Eisenhower administration was careful not to appear to be acting against its declared policy of supporting unity among Arab states as long as it expressed the wishes of Arab masses. Certainly, Egypt and Syria were not among the candidates that were nominated to form the ideal US model of Arab unity, however, Washington had no option except to take a positive position towards the new republic. Thus, the US's quick recognition of the UAR, against the wishes of the conservative Arab regimes, was viewed by decision-makers in Washington as the only means to bring Nasser back to the Western camp and to combat the perceived expanding Soviet influence in Syria. Accordingly, it can be said that the Eisenhower administration was 
forced to acquiesce to the stream of Arab nationalism and to its preeminent leader, Gamal Abd el-Nasser.

\section{Bibliography}

\section{Unpublished Primary Sources:}

The National Archives (USNA), Washington. General Records of the Department of State (Record Group 59), Confidential U.S. Department of State Central Files:

- Telegram no. 2745, the Embassy in Egypt to the Department of State, Cairo, February 28, 1957, 684A.86/2-2857.

- Telegram no. 604, the Embassy in Egypt to the Department of State, Cairo, August 31, 1957, 783.00/8-3157.

- Telegram no. 1424, the Embassy in Egypt to the Department of State, Cairo, December 11, 1957, 674.00/12-1157.

- Telegram no. 1803, Hare to Secretary of State, Cairo, January 21, $1958,674.83 / 1-2158$.

- Telegram no. 2044, Memorandum of Conversation, Yost to the Secretary of State, Syria, January 25, 1958, 611.83/1-2558.

\section{Published Primary Sources:}

United States Department of State. Glennon, John P., Editor. Foreign Relations of the United States (FRUS), 1955-57. Near East; Iran; Iraq, Vol. XII, Washington, D.C.: U.S. Government Printing Office, 1955-57:

- No. 161, Paper Prepared in the Bureau of Near Eastern, South Asian and African Affairs and the Policy Planning Stuff, Washington, December 5, 1956, pp. 383-7.

United States Department of State. Glennon, John P., Editor. Foreign Relations of the United States (FRUS). 1955-1957. Near East: Jordan-Yemen, Vol. XIII, Washington, D.C.: U.S. Government Printing Office, 1955-57:

- No. 76, Telegram from the Department of State to the Embassy in Saudi Arabia, Washington, April 25, 1957, pp. 111-2.

- No. 83, Telegram from the Embassy in Jordan to the Department of State, Amman, May 3, 1957-8 a.m., pp. 122-5.

- No. 349, Memorandum from the Assistant Secretary of State for Near Eastern, South Asian, and the African Affairs (Rountree) to the Under Secretary of State for Political Affairs (Murphy), Washington, March 18, 1957, pp. 614-7. 
- No. 355, Memorandum from the Assistant Secretary of State for Near Eastern, South Asian, and the African Affairs (Rountree) to the Acting Secretary of State, Washington, August 13,1957, pp. 632-634.

- No. 359, Noted of the Secretary's Staff Meeting, Department of State, Washington, August 19, 1957, 9:15 a.m., p. 639.

- No. 364, Telegram from the Department of State to the mbassy in Saudi Arabia, Washington, August 21, 1957- 7:52 p.m., pp. 645-6.

- No. 374, Telegram from the Consulate General in Istanbul to the Department of State, p. 658.

- No. 375, Memorandum of a Conversation with the President, White House, Washington, August 28, 1957, 10:30 a.m., pp. 659-60.

- No. 379, Telegram from the Embassy in Egypt to the Department of State, Cairo, September 1, 1957-7 p.m., pp. 664-9.

- No. 412, Telegram from the Mission at the United Nations to the Department of State, pp.728-9.

- No. 417, Memorandum from the Deputy Assistant Secretary of State for International Organization Affairs (Walmsley) to the Director of the Executive Secretariat (Howe), p. 738.

- No. 419, Memorandum of a Conversation, New York, November 7, 1957, pp. 740-4.

- No. 420, Telegram from the Embassy in Egypt to the Department of State, Cairo, December 11, 1957-4 p.m., pp. 774-6.

- No. 421, Telegram from the Department of State to the Embassy in Egypt, Washington, December 12, 1957-5:36 p.m., pp. 746-7.

United States Department of State. Glennon, John P., Editor. Foreign Relations of the United States (FRUS). 1955-57. Suez Crisis, July 26December 31, 1956. Vol. XVI, Washington, D.C.: U.S. Government Printing Office, 1955-57:

- No. 650, Message from the President to the Secretary of State, December 12, 1956, pp. 1296-7.

United States Department of State. Glennon, John P., Editor. Foreign Relations of the United States (FRUS). 1955-57. Arab-Israeli dispute, 1957, Vol. XVII, Washington, D.C.: U.S. Government Printing Office, 1955-57:

- No. 334, Telegram from the Embassy in Egypt to the Department of State, Cairo, May 29, 1957-3 p.m., pp. 631-2.

- No. 350, Telegram from the Embassy in Egypt to the Department of State, Cairo, July 2, 1957-5 p.m., pp. 677-9.

- No. 367, Telegram from the Embassy in Egypt to the Department of State, Cairo, August 24, 1957- noon, pp. 713-21.

- No. 392, Memorandum from the Assistant Secretary of State for Near Eastern, South Asian, and the African Affairs (Rountree) to the Secretary of State, Washington, November 4, 1957, pp. 785-788. 
- No. 398, Letter from the President to the Secretary of State, Washington, November 13, 1957, pp.795.

- No. 413, Telegram from the Embassy in Saudi Arabia to the Department of State, Jidda, November 28, 1957-noon, pp.827-8.

United States Department of State. Glennon, John P., Editor. Foreign Relations of the United States (FRUS), 1958-60. Lebanon and Jordan, Vol. XI, Washington, D.C.: U.S. Government Printing Office, 1958-60:

- No. 157, Telegram from the Embassy in Jordan to the Department of State, Amman, January 27, 1958- 11 a.m., pp. 268-70.

United States Department of State. Glennon, John P., Editor. Foreign Relations of the United States (FRUS). 1958-1960. Near East region; Iraq; Iran; Arab Peninsula, Vol. XII, Washington, D.C.: U.S. Government Printing Office, 1958-60:

- No. 3, Memorandum from the Assistant Secretary of State for Near Eastern, South Asian, and the African Affairs (Rountree) to Secretary of State Dulles, Washington, January 21,1958, NSC 5801: "Long Range U.S. Policy toward the Near East, pp.4-5.

- No. 9 Memorandum from Acting Secretary of State Herter to President Eisenhower, Washington, January 30, 1958, p. 36.

- No. 10, Memorandum of Discussion at the $354^{\text {th }}$ Meeting of the National Security Council, Washington, February 6, 1958, pp. 37-40.

United States Department of State. Glennon, John P., Editor. Foreign Relations of the United States (FRUS). 1958-1960. Arab-Israeli dispute; United Arab Republic; North Africa. Vol. XIII, Washington, D.C.: U.S. Government Printing Office, 1958-60:

- No. 182, Telegram from the Department of State to the Embassy in the United Kingdom, Washington, January 10, 1958- 3:52 p.m., pp, 401-3.

- No. 185, Telegram from the Embassy in Syria to the Department of State, Damascus, January 24, 1958-2 p.m., pp. 406-7.

- No. 186, Telegram from the Department of State to the Delegation at the Baghdad Pact Council Meeting at Ankara, Washington, January 25, 1958-2:41 p.m., p. 408.

- No. 187, Memorandum from the Acting Assistant Secretary of State for Near Eastern, South Asian, and the African Affairs (Berry) to the Acting Secretary of State, Washington, January 25,1958, pp. 409-11.

- No. 188, Telegram from the Delegation at the Baghdad Pact Council Meeting to the Department of State, Ankara, January 29, 1958midnight, pp. 412-3. 
- No. 191, Memorandum from the Secretary of State's Special Assistant (Greene) to the Deputy Assistant Secretary of State for Near Eastern, South Asian, and the African Affairs (Berry), Washington, February 5,1958, p. 191.

- No. 193, Telegram from the Department of State to the Embassy in Iraq, Washington, February 8, 1958-7:50 p.m., pp. 419-20.

- No. 196, Circular Telegram from the Department of State to Certain Diplomatic Missions, Washington, February 15, 1958-6:32 p.m., pp. 425-6.

- No. 197, Telegram from the Embassy in Egypt to the Department of State, Cairo, February 18, 1958-8 p.m., pp. 427-9.

- No. 199, Telegram from the Department of State to the Embassy in Iraq, Washington, February 21, 1958-4:22 p.m., pp. 430-2.

\section{Secondary Sources}

- Al-'Azm, Khaled (1973). Muzakkirt Khaled Al-A'zm, Vol. II, third edition, Beirut: Dar el-Mutaheda lil-Nasher, pp. 492-3.

- Anderson, Philip (1995). Summer Madness: The Crisis in Syria, August-October 1957, British Journal of Middle Eastern Studies, Vol. 22, No.1/2, Taylor \& Francis, Ltd, p.21-42.

- Ashton, Nigel John (1996). Eisenhower, Macmillan and the Problem of Nasser, Anglo-American Relations and Arab Nationalism, 1955-59, London: Macmillan Press LTD, pp.130, 144-5.

- Barrett, Roby C. (2007). The Greater Middle East and the Cold War: US Foreign Policy under Eisenhower and Kennedy, London: I.B. Tauris \& Co Ltd, p. 47.

- Dawisha, Adeed (2003). Arab Nationalism in the Twentieth Century from Triumph to Despair, London: Princeton University Press, pp. 187, 191-2.

- Eisenhower, Dwight D. (1965). The White House Years, Waging Peace, 1956-1961, London: Heinemann, pp. 199, 201-3, 262-3.

- Eveland, Wilbur Crane (1980). Ropes of Sand: America's Failure in the Middle East, New York: W.W. Norton, pp. 271-2.

- Ferrell, Robert H. (1981). The Eisenhower Diaries, New York: Norton, p. 323.

- Heikal, Mohamed H. (1988). Sanawat al-Ghalayan, Cairo: Markaz Al-Ahram, pp. 222-5.

- Jankowski, James P. (2002). Nasser's Egypt, Arab Nationalism, and the United Arab Republic, Lynne Rienner Publishers, pp. 106-9.

- Kerr, Malcolm (1967). Coming to Terms with Nasser: Attempts and Failures, International Affairs (Royal Institute of International Affairs), Vo. 43, No. 1, Oxford University Press, p.65-84. 
- Lesch, David W. (1992). Syria and the United States, Eisenhower's Cold War in the Middle East, Westview Press, pp. 112-3,118-120, 128, 158, 173, 202.

- Lesch, David W. (1995). Gamal Abd al-Nasser and an Example of diplomatic Acumen, Middle Eastern Studies, Vol. 31, No. 2, Taylor and Francis, Ltd, p. 362-374.

- Lesch, David W. (1998). When the Relationship Went Sour: Syria and the Eisenhower Administration, Presidential Studies Quarterly, Vo. 28, No. 1, Wiley on behalf of the Center for the Study of the Presidency and Congress, pp.92-107.

- Little, Douglas (1990). Cold War and Covert Action: The United States and Syria, 1945-1958, Middle East Journal, Vol. 44, No. 1, Middle East Institute, p.51-75.

- McNamara, Robert (2005). Britain, Nasser and the balance of Power in the Middle East 1952-1967 from the Egyptian Revolution to the Six Day War, Taylor \& Francis e-Library, pp. 94, 104-6, 118.

- Nutting, Anthony (1972). Nasser, London: Constable \& Robinson Limited, p. 225.

- Podeh, Elie (1993). The Struggle over Arab Hegemony after the Suez Crisis, Middle Eastern Studies, Vol. 29, No. 1, Taylor \& Francis, Ltd, pp. 91-110.

- Podeh, Elie (1999). The Decline of Arab Unity, The Rise and Fall of the United Arab Republic, London: Sussex Academic Press, pp. 41, 47.

- Seale, Patrick (1965). The Struggle for Syria: A Study of Post-War Arab Politics, 1945-1958, London: Oxford University Press, pp. 3158.

- Sorby, Karol (2000). The Struggle for Syria, The Road towards the United Arab Republic, Asian and African Studies, Vol.9, p. 213-234.

- Taha, Riad (1974). Qissat al-Wuhda wa al-Infisal: Tajribat Insan 'Arabi Khelal Ahdath 1955-1961, Beirut: Dar al-Afaq al-Jadida, p.73.

\section{Theses and Dissertations}

- Al-Jebarin, Abdulqadir Ismail (1988). The United States-Egyptian Relations, 1945-1958, Ph.D. Thesis, Faculty of Arts, Illinois State University, p.184.

- Al Otaiby, Sattam B. R. (2002). From Eisenhower to Kennedy: The United States' Policy of Accommodating the United Arab Republic, 
1958-1963, Ph.D. Thesis, Faculty of Humanities, University of Manchester, pp. 50.

- Geary, Brent M. (2007). A Foundation of Sand: U.S. Public Diplomacy, Egypt, and Arab Nationalism, 1953-1960, Ph.D. Thesis, Faculty of Arts and Sciences of Ohio University, United States of America, pp.192, 210-2, 228.

- Holland, Matthew Floyd (1994). A Role in Search of a Hero: America and Egypt from Roosevelt through Eisenhower, Ph. D. Thesis, Graduate College, University of Arizona, United States of America, pp. 138, 328.

- Yaqub, Salim Clyde (1999). Containing Arab Nationalism, The United States, the Arab Middle East, and the Eisenhower Doctrine, 1956-1959, Ph.D. Thesis, Faculty of the Graduate School of Yale University, United States of America, pp. 146, 190, 227.

\section{Websites}

- Nasser' Speeches (1957). Nasser's Statement to the Associated Press and the National American Broadcasting Company on 27/9/1957. URL:

http://www.nasser.org/Speeches/SpeechesAll.aspx?CS=0\&x=2\&lang=ar. Accessed on March 15, 2018. 